\title{
Criminologies of the Global South: Critical Reflections
}

Kerry Carrington, Bill Dixon, David Fonseca, David Rodríguez Goyes, Jianhong Liu and Diego Zysman

\section{Abstract}

This article attempts an ambitious undertaking by scholars collaborating from far flung parts of the globe to redefine the geographic and conceptual limits of critical criminology. We attempt to scope, albeit briefly, the various contributions to criminology (not all of it critical) from Argentina, Asia, Brazil, Columbia and South Africa, in alphabetical order. Our aim is not to criticize the significant contributions to critical criminology by scholars from the Global North, but to southernize critical criminology - to extend its gaze and horizons beyond the North Atlantic world. The democratization, decolonization and globalization of knowledge is a profoundly important project in an unequal and divided world where knowledge systems have been dominated by Anglophone countries of the Global North (Ball, this issue; Connell, 2007). Southernizing fields of knowledge represents an important step in the journey toward cognitive justice as imagined by de Sousa Santos (2014). While we can make only a very small contribution from a selected number of countries from the Global South, it is our hope that others may be inspired to join the journey, fill in the gaps, and bridge global divides.

\section{Key Words}

cognitive justice; criminological theory; decolonization of knowledge; southern criminology

\section{Introduction}

One of the major achievements of critical criminology is that it has moved the study of crime "into far more interesting, exciting, and productive paths and away from the tired and staid theories and research findings that explain next to nothing about crime and deviance" (Kauzlarich, 2013: 255). The 2013 special edition of Critical Criminology: An International Journal entitled "Crucial Critical Criminology" highlighted how convict, cultural, feminist, green, intersectional and realist criminologies had widened the criminological agenda. This article takes another step in that direction by outlining how the southernizing of criminology expands the criminological imagination beyond the North Atlantic world (Carrington et al. 2019). Criminologies from the Global South, while not all critical, have made important contributions to critical thinking about crime, justice and human rights, but are rarely registered in this field of knowledge. This article first describes what is meant by southern criminology 
as both a critique of critical criminology as narrowly defined and a contribution to it as broadly defined. It then maps the developments of criminological thinking in Latin America, South Africa, and Asia as examples of the challenges but also the prospects from which the project of southernizing criminology might usefully spring.

\section{What is Southern Criminology?}

The bulk of the world's academics, centers, institutions, journals, resources and universities reside in the English speaking countries in the Global North (Connell et al. 2017: 21). This is true for criminology as well as for all other fields of social science (Carrington, Hogg, and Sozzo 2016). In this global organization of knowledge, social and criminological phenomena in the "periphery" are investigated from the standpoint of purported universal theories and laws of development generated in "modern" or "Western" societies of the Global North (Connell, 2007). Countries in the Global South are mined for data; for example, Lombroso extracted what he believed to be examples of atavism from Asia, Australia and New Zealand (Carrington and Hogg, 2017). Empirical studies are conducted applying imported theory from the Global North, as in the case of strain theory tested many times by criminologists in China (Carrington and Hogg, 2017). It is often assumed that few, if any, original ideas or theoretical insights are yielded by conducting social or criminological research in the Global Southa phenomenon that Raewyn Connell, author of Southern Theory (2007), refers to as "metropolitan" thinking (Connell 2007: 215).

"Metropolitan thinking" has led to the academic institutionalization of criminology as a Northern enterprise, which simply assumes a transnational generalizability and transferability of knowledge (Bowling 2011: 363). Southern criminology challenges this bias, exposing the limits of these universal knowledge claims. It attempts to enlarge the criminological imagination to encompass experiences, ideas and theories from the Global South. But is does not seek the status of a subdiscipline or brand to further fragment critical thinking in criminology. Rather, it is a journey toward cognitive justice that seeks to bridge global divides (Carrington, et al. 2019:188). Southern criminology expands the repertoire of criminology (including critical criminology) beyond its heavily laden northern gaze. As a project, it seeks to harness and cultivate knowledges of and from the Global South that have been relatively unheard in the Global North (Carrington, Hogg and Sozzo 2016; Carrington et al. 2019). The southernizing of criminology pursues an open-ended endeavor to include multiple voices (e.g., feminist, Indigenous, peripheral, subaltern). Southern criminology also resonates well beyond any geographical divide, attracting interest as an intellectual project that seeks diversity, inclusivity, and innovation from scholars of the Global North (Carrington et al. 2019). One of the 
positive outcomes of this endeavor thus far has involved the emergence of new collaborations scholars of the Global South and those of the Global North who share a vision for democratizing the theoretical toolbox of criminology. This includes scholars who would identify with the broad label of critical criminology, and others who would not. This article is a product of that journey undertaken by a linguistically and culturally diverse international team of scholars working together to grapple with the enormity of the project of southernizing and decolonizing the large disparate field of criminology. It takes inspiration from previous attempts to decolonize and decenter social science (Connell, 2007; Chakrabarty, 2000; de Sousa Santos 2009/2014), including attempts to southernize criminology (Hogg et al, 2017). In Southern Criminology (2019), the authors summarize the project in this way:

For us 'the South' is a social construct that serves a number of purposes. It highlights and encourages autonomous knowledge-making in the Global South and advances claims for a more inclusive criminology. It provides a conceptual frame for resisting Northern hegemony in the production of knowledge and encouraging its on-going democratisation. Just as importantly, it seeks to explore and analyse global processes that shaped the worlds of both South and North and provides a vehicle for ensuring the events and relations of empire are inserted back into history and contemporary analysis and understanding. (Carrington et al. 2019:8)

Importantly, the concept of the "south" is deployed not only in a geographical fashion but also as a metaphor for the global inequality in power and knowledge. When taken in its metaphorical sense, the "south" refers to the peripheral voices located anywhere in the world, rather than in a geographical location. When we refer to the Global South, we are referring in loose terms to a geographical region. By inserting the violence of colonization back into the analysis of global patterns of crime, violence and criminalization, critical attention is to directed to the enclaves of the "Southern" in the Global North (Comaroff and Comaroff 2011). A good example of this is Elliot Currie's analysis of the rates of homicide victimization among African American men, which are 20 per 100,000 compared to 2.7 per 100,000 for white Americans (Currie 2017: 25-6). In other words, African American men are more than 7 times more likely to be a victim of homicide than other American men. At the end of slavery, Currie argues that the legacy of the slave trade entrenched racial disparities, devastating opportunities for African American men, who today experience rates of homicide akin to those of formerly colonized countries in the Global South. Hence, southern criminology is not confined to geographical limits as it can cross-fertilize and enhance understandings of crime and violence across a global empire that erected privilege and color-lines of disadvantage (Carrington et al. 2019: 184).

The project of southern criminology is not without its critics, who see it as: (1) running the risk of becoming a variant of comparative criminology that adopts uncritically mainstream metropolitan theories and concepts (Brown, 2018); (2) not the first to attempt to rattle the colonialist thinking 
embedded in criminological thought without much success (Moosavi 2018); (3) little different from mainstream criminology if it fails to adopt an Indigenous lens (Cunneen, 2018); or (4) just an impossible task given the sheer cultural and linguistic diversity of the Global South (Travers 2017). As Mossavi (2018) rightly points out, there have been previous attempts to unpack and jettison what he calls "westernised criminology" - to trans-nationalize it (Aas 2012; Bowling 2011) and to decolonize it (Agozino 2010, Cain 2000 and Cunneen 2011). What differentiates southern criminology from these post-colonial and Indigenous critiques, however, is its explicit rejection of orientialism, natavism and relativism - the romanticization of "the other" based on identity, indigeneity or ethnicity (Cain 2000). Colonialist thought is embedded so deeply in social science it is not possible to disentangle it completely (Chakrabarty 2007). Hence, a pure post-colonial or Indigenous lens is either a fantasy or an impossibility. But a criminology that aims to decenter, democratize and pluralize knowledge by injecting it with innovation, study and theory from the periphery is possible. Unlike the more extreme essentialist versions of post-colonial and critical race studies, the project of southernizing criminology does not set out to denigrate the contribution of northern criminology to the production of knowledge over the last century, but more to re-orient and re-focus it in a more useful way. Indeed, rather than creating divisions, a southern criminology seeks to build epistemological bridges. A southern criminology is based on the premise that an important form of decolonial action is achieved by "affecting and transforming the contents of Western science, through the use of knowledge, realities and cosmologies" of the south (Goyes, 2018:337).

To address Brown's (2018) assertion that southern criminology runs the risk of becoming little more than comparative criminology, we would point out that comparative criminology is not only limited by the lack of non-western comparisons (Liu, Travers and Chang, 2017), but when comparisons are drawn with Asian/Southern societies, they tend to be framed by an orientalism or elitism that constructs non-western societies as "exotic," "primitive" or the "other" (Carrington, 2017). Unlike comparative criminology, which measures forms of justice from the Global North as the benchmark from which all other societies are compared, southern criminology seeks "to contemplate life, crime and social order outside the metropolitan North, ... (and) to find new ways of thinking about phenomena so that the South is understood on its own terms" (Brown, 2018: 83). This is what we mean by southernizing criminology. It is a political, intellectual and empirical journey of retrieval that eschews oppositionism (Carrington, Hogg and Sozzo, 2016).

In what follows, we attempt to redefine the geographic and conceptual limits of critical criminology, by scoping, albeit briefly, the various contributions to criminology (not all of it critical) from Argentina, Asia, Brazil, Columbia and South Africa (presented in alphabetical order). There is no logical rationale for the choice of countries, other than these are the places where the authors of this 
article either live, work or have conducted collaborative research. Again, our aim is not to find fault with the significant contributions to critical criminology by scholars from the Global North, but to southernize critical criminology - to extend its gaze and horizons beyond the North Atlantic world.

\section{Criminology in Argentina}

Compared to other Latin American countries, an Italian-influenced positivist criminology developed early in Argentina in late nineteenth century. This "great Italian immigration" to Argentina in the 1870s brought a close cultural bond with Italy, which helps explain this rapid diffusion. The criminological science of the "Scuola Italiana," along with a positivist approach, more generally, played a very important role in the construction of the Argentinian national state-one that aimed to show Europe and the rest of the world its degree of civilization and development.

The discourse of scientific criminology was not only imported, but translated:

The local actors translated elements of the rationalities and technologies for the government of crime produced in other cultural contexts, but in so doing they altered their character considering both the 'empirical' elements (which referred to their own context) and the 'non-empirical' elements created by the translator's own theoretical and political inventiveness. The 'rejections' and 'adaptations' of elements of these cultural artefacts that travel between 'here' and 'there', produced by local actors in the local context, led us to think of these translations -bearing in mind the expresion 'traduttore traditore' -as true 'methamorphoses' of the thing translated" (Sozzo 2001, 2011: 186-187)

This translation was undertaken in order to deal with local conflicts linked to the great immigration, the exclusion of the Indigenous population surviving the great repression of the $1870 \mathrm{~s}$ (now considered a "genocide"), and other attempts to establish a new social order. We should not assume, however, that all silenced theories, generated from the Global South, were necessarily emancipatory or critical. Some of these Argentinian-Global South theories also helped sustain the status quo. Thus, for example, the positivist and socialist physician and influential Argentinian criminologist, José Ingenieros (1916), helped bring Italian positivism to the South in his proposition for a classification of psychological pathologies to explain criminal behavior. His theories had some success among his European colleagues and his work was even translated into English, French, Italian and Portuguese.

In order to chart the development of criminology in Argentina, it is important understand some of the country's larger political history. During the Cold War and the fear associated with the spread of socialist revolutions in Latin America, anti-communist military dictatorships used police repression, death and torture as tactics to control the population. In Argentina, in particular, military 
dictatorships deployed a system of "systematic disappearance" of thousands of people. As a result, many academics and scholars fled Argentina to study in countries of the Global North, such as Italy, Mexico, Spain, the United Kingdom and the United States. There, they began to develop a new antistate criminological orientation-one that challenged the positivist tradition and that evoked the radical criminologies of the Global North, but that also attempted to be uniquely Latin American. These experiences abroad also helped to develop a new critical criminological discourse beyond the correctional, religious and humanist critiques of criminology of previous years.

For example, the Argentinians, Marcó del Pont, Carranza and Pegoraro, produced works inspired by The New Criminology of Taylor, Walton and Young (1977). Roberto Bergalli and -Emilio Garcia-Méndez discussed these theoretical frameworks from exile in Spain, produced critical criminological literature (or "criminología de la liberación"/"liberation criminology," as it came to be termed at the time), and disseminated the works of European and American criminologists through translations of Punishment and the Social Structure by Rusche and Kirchheimer (1984). Bergalli and García-Méndez also translated works of the critical school of Bologna by Melossi and Pavarini, to which they contributed prologues, epilogues, and critical reflections on the economic politics, structure and the repressive laws and practices of the Argentinian dictatorship and other authoritarian regimes in Latin America (See Pavarini 1983 and Baratta 1986). In so doing, they sought to apply theoretical developments from the Global North to understand socio-political-economic contexts in Argentina and other Latin American countries.

Bergalli $(1982 ; 1989)$ also played an important role in discussions with critical scholars trained in different areas of the Latin American cultural dependence on the economic and political centers of the Global North. In addition, he interrogated the concept of "social control," and suggested the term "sociology of criminal control" in lieu of "criminology" for the name of this new form of Latin American thought. Bergalli criticized positivist approaches that equated common delinquency and political subversion, as well as positivism's role in propping up the economic order of dictatorships-what Bergalli referred to as a "criminology of terror" (see also Manifiesto del Grupo Latinoamericano de Criminología Crítica, Azcapotzalco, México, 1981, in appendix of Bergalli 1982).

Since the 1980s, the work of Argentinian criminal jurist and judge, Eugenio Raúl Zaffaroni $(1982,1988 ; 1993 ; 2015)$, has had a profound impact on Latin American criminology as a whole. As a judge in different Argentinian courts, including the Supreme Court of Argentina, Zaffaroni exercised restraint, restricting the most punitive applications of criminal law. Today, he is a member of InterAmerican Court of Human Rights. It bears mention that Zaffaroni did not come to critical thinking through Marxism, and he prefers to use concepts closer to international human rights discourses. But 
he has been an immensely important historical figure as both an academic and a judge-who has helped bring together various radical and critical approaches anchored in Latin American history (abolitionism, rights-based, and, to a lesser extent, left realist criminology).

In addition to his work on the penal problems of Latin America, Zaffaroni proposed an anticolonial theory that, based on common tropes (such as the conflict between the police state and the rule of law), incorporated some concepts from criminal sociology and anthropology into a normative and critical theory of criminal law and punishment. He called this approach "Teoría Agnóstica de la pena" - or an "agnostic theory of punishment" - one that acknowledges the real harm that penal systems cause in societies with extreme inequality. Although not an empirical researcher, like many jurists and practitioners of Argentinian and Latin American rights, Zaffaroni's work became an important gateway to criminological and socio-juridical studies in law faculties. Another of his theoretical approaches, known as "realismo jurídico-penal marginal" or "criminal legal realism from the edge" imagined a criminal law and a criminology focused on the characteristics and problems of Latin American countries colonized since the fifteenth century and, therefore, "from the edge or margins of the central world." Finally, Zaffaroni helped spur the field of genocide studies in Argentina-one committed to the study of historical and contemporary genocide under various reigns of colonial rule, globalization, and military dictatorship (Zaffaroni 1982, 2015).

In 1983, with democracy restored, the democratically elected President Raúl Alfonsín established the first truth commission - the National Commission of Disappeared People (Comisión Nacional sobre la Desaparición de Personas or CONADEP) - to hear evidence from Argentinians about human rights abuses suffered during the previous military dictatorship (1976-1983). The work of the CONADEP proved, without doubt, that clandestine military-run detention centers of torture had been part of an entire system of state-supported terrorism. The final report, with the complete record of abuses, entitled Nunca Más (Never More) (1984), was the first published report of a truth commission anywhere in the world. The truth commission led to successful prosecutions and convictions of high ranking military officers and their accomplices for crimes of aggravated murder, kidnapping and torture (ZysmanQuirós 2017, 2018). A group of jurists and legal philosophers, such as Carlos Nino (1996), participated as presidential advisers in these trials. Nino later produced theories on liberal criminal law, human rights and punishment that spurred further international philosophical, juridical and sociological theorization about crimes of state and punishment in Argentina and abroad. These important socio-legal theories have contributed substantially to our understanding of transitional justice, state crime and genocide, and have shaped the operation of the United Nations International Criminal Court. 
In our concluding remarks, we return to the importance of these groundbreaking contributions of critical thinking from Argentina to the study of state crime and mass atrocity in other contexts and countries. Before doing so, however, we note a phenomenon that continues to plague other criminologists of the Global South. The journal Delito y Sociedad (Crime and Society), first published in 1992 and now available for free on-line, publishes an array of critical thinking about crime, justice and law in Argentina and the Latin American periphery, more generally. It was founded by Juan Pegoraro at the Universidad de Buenos Aries and is now published jointly with the Universidad Nacional del Litoral and edited by Máximo Sozzo a key figure in the development of southern criminology (see, e.g., Carrington et al. 2016, 2018, 2019). Because the journal is published in Spanish, English-speaking critical thinkers from the Global North have not been able to learn about the robust tradition of critical criminology in Argentina. As we will see in the rest of this article, language barriers have prevented thinkers in the Global North from appreciating uniquely Southern approaches to crime and justice, and have contributed to Northern assumptions about the presence and explanatory power of critical thinking outside the metropole.

\section{Criminology in Asia}

The emergence of criminology across Asian societies

Asia is a vast and diverse region of the world that stretches from the Middle East to Indonesia-with equally huge differences in culture, custom, economics, language, politics and religion. This short overview cannot encapsulate fully this diversity and thus focuses more narrowly on Southeast Asia. Jianhong Liu (2016), elected in 2006 to serve as the first president of the Asian Criminological Society (ACS), argues that the development of criminologies in Asia can be divided into three phases-many of which are over-lapping and not strictly linear in terms of a timeline. The first stage can be characterized by the uncritical transportation of ideas from the west to Southeast Asia; the second can be understood as involving testing and adapting and elaborating or rejecting imported ideas; and the third and most fruitful has been the development of distinct Asian criminological paradigms (Liu 2016).

Criminology is a relatively new field of study and research in many Asian societies. Around the turn of the twenty-first century, when scholars from Asia who had undertaken their training in criminology (and the social sciences, more generally) at universities in North America and Europe returned home to teach at universities in Hong Kong, Japan, South Korea and Taiwan, they tended to use key texts translated from English into their native language - texts which relied heavily on theories and studies from the western world (Liu, 2009:3). Some of these scholars also undertook their own translations of criminological articles and books (Cao 2008), but the effect was the same: the 
establishment of an historical precedent of vertical alignment into the global organization of knowledge (Carrington, Hogg and Sozzo, 2016), which marginalized the contribution of distinct Asian theories of crime and justice. It bears note, though, that at the time, many of these scholars undertook efforts to build some of the first degree programs in criminology in Southeast Asia, laying the foundation for the further growth and development of Asian criminology, described below.

\section{Testing and adapting and elaborating or rejecting concepts from the Global North}

In addition to translating key Western texts, many of the studies in the first stage entailed little more than applying uncritically established Western criminological concepts or northern theories to Asian contexts. Gradually, scholars working on and in Southeast Asia began to evaluate the generalizability of Western criminological ideas (e.g., Agnew's (1992) general strain theory; Gottfredson's (2006) social control theory) and to assess the feasibility of replicating Western criminological approaches, policies and practices in different Southeast Asian situations and settings (e.g., Jiang et al 2013:220; Takagi and Kawachi's 2014). Examples here include the re-working of routine activity theory, situational action theory and institutional anomie theory (Messner 2014; 2015).

Under the guise of comparative criminology, "general theories" of crime causation were "tested" against low crime rate societies in Asia (Liu, 2009:3; Leavitt 1990; Mattei 2006; Reimann and Zimmerman 2006; Nelken 2010). In general, comparative criminology has tended to construct the practices and institutions of crime and justice in the Global North as the benchmark from which to measure or compare others-a troubling development given that many such comparative studies have been conducted mainly by researchers from the wealthier countries of the English-speaking Global North (Liu, 2009, Liu, Travers and Chang, 2017). Leon Moosavi (2018:1) refers to this approach as the "westernization of criminology" and argues that this has happened, not because non-Western criminologies and scholarship have not existed, but because such work has been ignored. He outlines the significant contributions of Syed Hussein Alatas, a Malaysian social scientist, to understandings of crimes of the powerful, and points to the extensive body of scholarship in China, India and Japan that was simply ignored by western-centric criminology (Moosavi, 2018:4 )-a common theme throughout this article.

Perhaps unsurprisingly, many of the quantitative studies applying mainstream criminological theories to Asian contexts have produced contradictory findings. Strain theory, for example, has found support from some studies (e.g., Bao et al. 2014; Cheung, Ngai and Ngai 2007; Bao, Haas and Pi 2007; Cheung and Cheung 2010), but none or only partial support from others (Ngai and Cheung 2005; Wong 2001). As further illustration, Agnew's (2015) argument that as Asian societies become more 
westernized, the causes of strain will become more similar, overlooks the vast disparities between Asian cultures (Liu 2009). Similarly, Carrington (2017) has argued that it makes little sense to apply a theory that assumes crime is driven by individualism and materialism to the Confucius and collectivist cultures of diverse Asian societies (Carrington 2017).

\section{Asian Criminological Paradigms}

The third and most recent stage in the development of criminology across Asian societies is one characterized by increasing confidence and independence. In establishing the Asian Journal of Criminology, in 2006, published in English, Jianhong Liu sought an avenue for promoting Asian criminologies with shared conceptual frameworks (Liu 2009: 7), and the journal has become an important scholarly avenue for "a range of AsianPacific countries/regions including greater China, India, Japan, South Korea, Israel, Philippines, Thailand, Turkey, Pakistan, Indonesia, Sri Lanka, Cambodia, Australia, the Golden Triangle, Southeast Asia, and the Asia Pacific region as a whole" (Liu, 2009: 8). At the time of this writing, the journal had published 41 issues, is now rated in the top quartile of SciMago rankings for journal quality, and is included into Web of Science SSCl index - a significant achievement for a journal outside Europe or America. This achievement, against the backdrop of a ranking system stacked in favor of journals from Global North, is a sign of growth in interest and scholarly research of criminology across Asia. The journal is multi-disciplinary in scope, publishing a variety of forms of scholarship, and multi-methodological in its orientation, accepting work employing qualitative, quantitative and evidence-based research methods. To be sure, while not all the articles take a critical approach, the journal's very existence has attempted to challenge the hegemony of Western thought by disseminating research undertaken by Asian scholars about Asian societies and by bridging global gaps in knowledge.

Having an avenue for publishing new ideas has led to the creation of theories based on distinctly Asian realities. One example of this is the notion of "relational justice," which attempts to explain the large differences between Western and Confucian concepts of crime and justice (Liu $2014 ; 2$ 016). The theory proposes that cultural differences produce different concepts of crime and justice. Whereas the preponderance of Western criminological theories tends to focus on individuallevel offending and individualistic explanations of crime causation, Asian concepts-particularly eastern Asian ones-emphasize ideas about "relationism." Relationism is associated with attachment, harmony and honor, while Western individualism stresses independence, individual rights and material success. Furthermore, relationism is associated with a "holistic thinking mode," while individualism suggests a more "analytical thinking mode." Holistic thinking "involve[es] an orientation to the context or field as a whole, including attention to relationships between a focal 
object and the field, and a preference for explaining and predicting events on the basis of such relationships". Analytical thinking "involves a detachment of the object from its context, a tendency to focus on attributes of the object to assign it to categories, and a preference for using rules about the categories to explain and predict the object's behaviour" (Nisbett et al 2001, p293). Thus, the notion of "relational justice" uses cultural differences of individualism and relationism to explain differences in the criminal justice systems and behavior (Liu et al, 2016; Liu 2017a).

The third stage has also been characterized by an increased institutionalization of criminology at universities in China, India, Japan, Malaysia, the Republic of Korea and Singapore. In the People's Republic of China, for example, the discipline of criminology is now accepted in a university system that is engaging increasingly with international scholars. There are more opportunities for collaboration with scholars from other countries than previously, and interest in China's systems of crime control and justice are attracting more attention from scholars abroad (Coa and Hebenton, 2018:4). Coa and Hebenon (2018:5) conclude that "with increased international exchange of scholars, and appropriate cross-national research, its sustained further development or 'rise' is reassured."

Despite these welcome developments, one of the obstacles to the development of Asian criminologies has been the diversity across Asian cultures and societies, "manifested in different languages, different legal systems, and diversity in crime and crime control systems and practices" (Liu 2009:4). The lack of a single language means "discourse between Asian criminological scholars is sporadic" (Liu, 2009:4), inhibiting collaboration among scholars and preventing the creation of a "paradigm for Asian criminology" (Liu, 2009:4). Indeed, at an historic meeting in December 2009, about 50 criminologists from 14 countries and areas in the Asian Pacific region gathered in Macau to discuss ways to overcome fragmentation and the obstacles of multilingualism. There, they established the ACS, noted above, and held its first annual conference. Since then, nine more annual conferences of the ACS have been held in the following places: Chennai (2010); Taipei (2011); Seoul (2012); Mumbai (2013); Osaka (2014); Hong Kong (2015); Beijing (2016); Cairns (2017) (co-hosted with Queensland University of Technology's Crime and Justice Centre); and Malaysia (2018). The registered number of participants has been as high as 575 in Japan, and more than 300 convened in Cairns. The hope is that the ACS annual conference will continue to assist with the growth and development of criminology in Asia and the Pacific, providing a venue for collaboration and the sharing of ideas of scholars from vastly varying cultural and linguistic backgrounds.

\section{Pathways Ahead}

Prominent scholars from outside of Asia have recognized the growing significance of Asian criminologies to the wider development of criminological theory and research (Messner 2014, 2015; 
Braithwaite 2014, 2015; Walklate 2016; Sampson 2015; Agnew 2015; Belknap 2016; Carrington et al. 2016; 2018; 2019). As Braithwaite (2015:1) observes, “Asia's most important contribution to global criminology is therefore in opening its eyes to completely new ways of seeing, as opposed to adjusting, testing, or revising western theories in light of eastern experience." He points to the distinctive contributions of peace building and reconciliation practices from Afghanistan, East Timor, Indonesia, Nepal, Pakistan, and Polynesia, and shaming and restorative justice practices in Japan, as distinctive insights from which the rest of the world could and should learn. Braithwaite (2015) laments the fact that Asia has been an empirical testing ground for western theories, and urges Asian criminology to be steered by Asian scholars.

The rapid growth of Asian criminologies in recent years has played a key role in linking the Global North to the Global South, the West to the East. The primary strategies pursued by criminologists in Asian societies over the several decades represent a shift from simple testing of Northern concepts and theories to more complex theoretical work, and now (finally!) the task of proposing conceptual innovations and theories based on Asian paradigms (Liu, 2017b). Asian criminology has expanded the overall theoretical toolbox through the "transportation of theories, elaboration of theories, and proposing new concepts and theories based on the empirical grounds of Asian contexts" (Liu, 2017b: 73).

For those engaged in the project of democratizing and southernizing criminology (Carrington et al. 2018), the significance of emerging Asian criminologies is twofold. First, it links North to South via the East, creating a bridge for innovative knowledge creation and transfer: the rapid development of new relationships and, at the same time, the strengthening of existing, East-South, South-South and South-North collaborations (Carrington et al 2019). Second, Asian criminologies have increasingly challenged the hegemony of northern global knowledge systems (Carrington et al. 2016; 2019). This serves a larger goal insofar as it helps to dismantle assumptions of Global Northern intellectual superiority, while generating specific interest in Asian approaches and topics in criminology, in particular, and the social sciences, more generally.

\section{Criminology in Brazil}

In order to understand current criminological thought in Brazil, it is important to take into consideration the historical background of the field in the country. As in Argentina, the early arrival of criminological positivism to Brazil at the end of the nineteenth century left an important imprint on the development of the discipline. Later, the weakening of criminological positivism determined the 
fate of the entire field, resulting in the almost complete disappearance of criminological studies for many decades. The reception of critical criminology in law schools during the 1970s marked the reappearance of the discipline, influencing the adoption of a few progressive legal measures at the end of the Brazilian military government (in the mid-1980s). In more recent years (and since the 1980s), the skyrocketing rates of homicidal violence and other crimes in the country has placed increasing attention on crime, giving rise to empirical studies of this phenomenon and creating the prospects for a thriving area of critical research. We flesh out this history and trajectory in the sections below.

\section{The Arrival of Criminological Positivism}

As in many other countries in Latin America (see del Olmo, 1981), the historical development of the discipline of criminology in Brazil began with the arrival of criminological positivism, which helped Brazilian scholars to formulate ideas about crime and criminals, and articulate notions of dangerousness and social defense. In Recife, São Paulo and Rio de Janeiro, criminological positivism prospered in law schools and medical schools, as legal and medical scholars vied for prominence in explaining criminal behavior (Ferla, 2009)-as evidenced, in part, by the works of Tobias Barreto (1884) and Nina Rodrigues (1884), which made reference to Cesare Lombroso. Somewhat surprisingly, scholars in the Brazil were aware of the debates taking place in continental Europe in the late nineteenth and early twentieth centuries, and even managed to engage in scholarly exchange with the main researchers in this tradition (Alvarez, 2003).

Many of the Brazilian scholars in this positivist tradition adopted racial classifications (Dias, 2017) and discourses emerging in this context had clear eugenicist overtones (Schwarcz, 1993). Notwithstanding a few dissonant voices at the time that supported more progressive-and less racialized-ideas about crime, criminals and criminality, the predominant approach supported the construction of a typology of criminals based on prevailing racial prejudices (Alvarez, 2003). Concerns about dangerousness and social defense were also expressed in the literature of the period (Dias, 2017), most probably as a reaction to the end of slavery, growing urbanization and an enhanced fear of social unrest in the streets (Cancelli, 2001).

Criminological positivism left an important mark on much of the legislation of the period; for example, the implementation of parole and security measures (medidas de segurança) was clearly the result of the influence of this approach (Ferla, 2009). The adoption of a Code of Minors (1927), as well as the adoption of rehabilitation as the main rationale for punishment, also reflected debates around criminological positivism and social defense (Alvarez, 2003). While Brazilian criminology was to 
undergo shifts in the ensuing years, positivism has had a lasting influence and, to some extent, still guides the development of policies and discourses in the criminal justice system.

\section{The Marginalization and Resurgence of Criminology}

After a thriving beginning in the turn of the 20th century, criminology was relegated to the margins of academic debates in the aftermath of World War II. Although the arrival of the 1940 Criminal Code was still partially influenced by criminological positivism, its main underlying rationality was legal positivism. The arrival of legal positivism led to a privileging of doctrinal studies of criminal law over criminological study in Brazil.

Nélson Hungria, a renowned legal scholar and later a Justice in the Brazilian Supreme Court, became the most strident advocate of a pure doctrinal criminal law, calling for its insulation from the influence of criminology and other fields of knowledge (Sontag, 2009). This scholarly trend led to the abstraction and systematization of criminal law, dissociating it from the vicissitudes of everyday life. Criminology thus became known as the "auxiliary discipline of Criminal Law" (Hungria, 1943)-a secluded area in law schools and a marginalized niche in the study of forensics in schools of medicine. Indeed, law schools shunned criminology in the early years after World War II, focusing instead on discussions about the legal concept of crime and the technicalities of criminal responsibility. Criminology became almost exclusively a clinical field, restricted to the work of psychiatrists and a few social workers in penitentiaries and asylums in the country. During this period, criminology's loss of prestige prevented any possibility of its advancement.

Several critics, however, realized that the eschewal of criminology and abstract discussions of legal doctrine had resulted sterile debates, devoid of any connection to real world social problems (Batista, 1990; Pimentel, 1980). Accordingly, in the beginning of the 1970s, criminology began to make a timid reappearance in legal circles. In 1974, it was reintroduced into graduate studies in São Paulo and later in other universities around the country (Pimentel, 1980). During this decade, while Brazil still suffered under a military dictatorship, critical perspectives began to germinate in the more progressive universities - a hallmark of resistance against an authoritarian government. Following the trend in other Latin American countries, critical scholars helped to build important resistance movements against dictatorships in the region (Bergalli, 1989; Castro, 1987; Zaffaroni, 1988).

The arrival of critical criminology in Brazil was accompanied by a denouncement of the inherent bias of the criminal justice system and the inequalities involved in the criminalization process, which targeted almost exclusively members of the lower and formerly enslaved classes. The works of Lyra Filho (1972) and Santos (1981) challenged the legal system's oppression of subaltern groups, and 
in the 1980s, critical criminologists, along with liberal lawyers, helped forge important changes in the law, culminating in the comprehensive reform of the Criminal Code and the enactment of a law for regulating the imposition of criminal sanctions across the nation. Since the return of democracy and the adoption of a new Constitution in 1988-and given both the traditional prestige of lawyers in the country and the expansion of state bureaucracy through legal professionals-a few law schools have continued to carry the torch of critical criminology (Batista, 2011). But the emergence of a more empirically oriented approach to crime control and punishment has attracted more attention in these last decades.

\section{Methodological Approaches and Empirical Studies of Crime and Violence}

In order to more fully appreciate the history and development of criminology in Brazil, it is necessary to examine some of the methodological shifts and preferences that have transpired over the years. For example, ethnographic accounts appeared timidly in the beginning of the 1980s, when the reality of favelas became more widely known (Zaluar, 1994). The return of democracy, which put an end to censorship and allowed for the return of social movements, brought about the possibility of shedding light on the lives and social organization of people living in vulnerable conditions (Holston, 2008). The inventiveness, hardships and violence of marginalized areas continues to be an area of academic interest, providing a wealth of knowledge and revealing a complex and multifaceted web of social interactions (Valladares, 2000; Zaluar and Alvito, 1998)

The import of some statistical tools and geocoding technologies has created a new group of specialists, who have helped to evaluate and design strategies in policing and punishment practices. These researchers have amassed an important amount of data (Beato, 2012) in their assessments of the institutional operation of criminal justice agencies (Paixão, 1987) and the evaluation of the causes and impact of violence on the fabric of society (Peralva, 2000; Waisselfisz, 2011). In total, their work constitutes a burgeoning body of literature in the study of crime and public security.

In recent years, a few schools and centers have appeared, concentrated around a few leading investigators and research grants, such as NEV (Núcleo de Estudos da Violência) in São Paulo and CRISP (Centro de Estudos de Criminalidade e Segurança Pública) in Minas Gerais. A number of centers and graduate programs have also been created over the last years, as in Brasília, Porto Alegre, Rio de Janeiro and São Carlos. Since 2007, the interrelation between governments and research centers has prompted the creation of the Forum Nacional de Segurança Pública, an institute in charge of compiling statistics, publishing papers, developing policies and offering a nationwide network for researchers. 
Criminologists and other scientists specializing in the study of crime and crime prevention have become advisors for public policies and reform, focusing on the amelioration of social inequalities, the empowerment of marginalized groups, and respect for human rights. These new studies refer only occasionally to foreign literature in their empirical research or theoretical formulations. Although this could be viewed in a positive light, as the inception of a genuine Brazilian school of thought, most of the methodological tools are imported and not much attention has been directed at historical developments and long-term causes of the problems in the Brazilian criminal justice system. To their credit, this group of researchers has accomplished the goal of serving as influential advisors to policy-makers, but they still fall short of providing a comprehensive explanation for the predicament of crime, crime control and punishment in the country.

Finally, a growing number of applied social scientists have begun to research crime and violence in Brazil. This work has been undertaken independently of the research and scholarship in law school, and is remarkable in that it has entailed the complete abandonment of the traditional criminological terminology and the rejection of any references to existing criminological literature (Lima and Ratton, 2011). Under the label of "Public Security" (Segurança Pública), this work has been marked by a shift towards the study of rising crime rates and the ensuing public uproar around the fear of crime (Benevides, 1983).

\section{Pathways ahead}

Astonishing high levels of homicidal violence and imprisonment in Brazil represents an unprecedented predicament (Fonseca, 2018), and addressing crime control and remains one of the main challenges for the country's future. Much effort will be required to make sense of the situation and to ameliorate this serious social problem. Unfortunately, changes in government over the last months have indicated a trend towards more repressive, exclusionary and punitive measures in crime control and punishment.

In some respects, the preference for empirical research in Brazil may be a welcome phenomenon (although such an approach lacks theoretical sophistication and historical contextualization). In a country still devoid of reliable data, this empirical direction might prove quite promising for it offers the possibility of bringing together critical criminology and current empirical studies on crime and violence under the same umbrella. In other words, rather than viewing empirical methods as the antithesis of critical criminology (see Lynch et al. 2017 for a general discussion), one might consider such empiricism as holding the keys to data that, when subjected to critical analysis, could contribute to the implementation of more effective policies. 
In sum, just as interest in criminology, as a whole, has ebbed and flowed in Brazil over the years, so, too, have critical approaches. In recent years, the incorporation of feminism and race studies into various research agendas has helped bridge gaps between legal scholars and critical criminologists (Andrade, 1997). The combined forces of these two perspectives might become a fundamental bulwark against the exclusionary and punitive approaches engendered by the recent changes in the political direction of the country.

\section{Criminology in Colombia}

This brief account of the history of criminology in Colombia advances four main arguments. First, that historically, Colombian self-denominated criminology ${ }^{1}$ has been informed by an internal-colonialist logic. Second, that most of the Colombian self-denominated criminology, at least until recently, has been derivative and unimaginative and not at all critical. Third, that to find a real endogenous innovative Colombian criminological thinking, it is necessary to look beyond what has been selfdenominated as criminological work. Fourth, that most of what could have been most criminologically innovative has been neglected by the discipline both within the country and internationally.

Aniyar de Castro (1987) has asserted that "Latin American criminology" is not the same as the criminology produced by local economic, intellectual and political elites in Latin America. Echoing her words, we argue that to find critical contributions to understandings of crime, violence and justice in Colombia, one must look beyond what falls under the label of criminology. Each of these four arguments follows a loose chronological order of criminology (see Marroquín Grillo and Camacho Flórez 1985; Benavides Banegas 2017). This history has the following five periods.

\section{Appearance of Criminology in Colombia (1930-1940)}

Criminology first arrived in Colombia in the 1930s, upon the return intellectual elites, who had gone to Europe (mainly Italy) to advance their studies. Marroquín Grillo and Camacho Flórez (1985) describe those years as a moment in which international capital and leftist unions were challenging the power held by large traditional landowners who had dominated the country for centuries. As with Argentina and Brazil, discussed above, the first criminology in Colombia fell in the positivist vein. The power elites at the time welcomed this approach because racist idea of humans as situated in different stages of development provided these elites with scientific support for applying strict and repressive policies

\footnotetext{
${ }^{1}$ We use the term "self-denominated criminology" to differentiate between what authors, themselves, may consider to be criminology from what fits into the scope of criminological interest without carrying the label of "criminology." The four arguments we advance here apply only to "self-denominated criminology" - only to those areas of research and those works that have self-identified as (or actively embraced the term) "criminology."
} 
that favored their permanence as elites. Those power elites saw in criminology a handy tool to legitimize the drastic measures they were taking to suppress social uprisings. Tellingly, the Colombian penal code adopted in 1936 was a copy of the penal code drafted in 1921 by Enrico Ferri-one of the famous founders of criminological positivism. Criminologists of the time were influenced by the notion of a criminal anthropology and focused their research on prison studies. Even progressive, left-wing leaders of the time, such as Jorge Eliecer Gaitán or Luis Carlos Pérez, who usually advocated for the rights of oppressed groups, embraced positivist ideas uncritically (Marroquín Grillo \& Camacho Flórez, 1985).

The initial emergence of criminology in Colombia was also strongly informed by an internalcolonialist logic, which fit perfectly with early positivist conceptions of criminals as "inferior groups" that needed to be repressed for the benefit of society. Mondaca (2017) defines "internal colonialism" as "a structure of social relations of domination and exploitation among heterogeneous cultural groups within a single state" (p. 37). Internal colonialism racializes relations between colonizers and colonized groups, helps stabilize a market system dominated by those controlling capital, establishes northern science as the ultimate knowledge, and allocates the control of formal and informal systems of social control to those human groups considered as superior (Mondaca, 2017). The arrival of criminology in Colombia had all those consequences or features. Indeed, several Colombian authors concur that criminological positivism, which held sway in Colombia until the 1980s and which is still informing criminal policy, has "been important to control subaltern groups and to constitute their identities" (Benavides Banegas, 2009, p. 8; see also Benavides Banegas, 2017; Marroquín Grillo \& Camacho Flórez, 1985; Silva García, 2012).

The First Criminological Silence (1940-1968)

A period of the "criminological silence"-where criminological input was absent from both scholarly and political debates-extended from 1940 to 1968 and coincided with a very violent period in the country. At the time, a semi-capitalist economic model was in place-one that had traditional local landowners and foreign capital as equally powerful central actors. At the political level, the simultaneous existence of these two powers (traditional local landowners and foreign capital), added to inequities in land distribution, resulting in a wave of violence between conservative and the new liberal sectors (Marroquín Grillo \& Camacho Flórez, 1985, p. 284; Medina Gallego, 2009). Peasants and other rural populations suffered greatly and were forced to migrate en masse to the cities. Furthermore, both guerrilla groups and paramilitary groups began to mobilize during this time (Goyes, 2015). Because academic criminologists assumed that their focus should be on that which is proscribed and punished by law, they remained silent about all these forms of violence. 
While criminologists seemed oblivious to or uninterested in extrajudicial violence, anthropologists, economists, historians and sociologists did engage with issues of drug dealing, internal armed conflict, and mass murders, in an original and non-derivative style without even mentioning the concept of criminology (see, e.g., Benavides Banegas, 2017; Silva García, 2011; Silva García, 2012). It is perhaps the endogenous Colombian discipline violentology, which Cartagena (2016) defines as the general study of violence "including within it the myriad of characterisations of that phenomenon" (2016: 63), that best illustrates the argument that it is necessary to look beyond what has been self-denominated as criminological work to uncover the critical study of crimes of powerful. During the mid-1950s, a number of texts appeared that exemplified the violentological approach to trying to understand the violence in Colombia. These included autobiographical accounts written by combatants, explaining their reasons for violence, as well as journalistic reports about dictatorships and mass murders. While few criminologists research, studied or wrote about one of Colombia's most violent periods, anthropologists, geographers and sociologists were attempting to comprehend and document the violence in Colombia. For example, La violencia en Colombia [Violence in Colombia] (Fals Borda, Umaña, \& Guzmán Campos, 2016 [1962]) attributes the violence in Colombia at the time to social dynamics, such as dysfunction in all basic social institutions .

Criminological Resurgence and the Formation of a Critical Perspective (1965-1990)

In 1965, criminology resurfaced in Colombia, with scholars employing positivist methods. But it remained a minor field, primarily the province of law faculties and the Colombian National Police (Marroquín Grillo \& Camacho Flórez, 1985). Nonetheless, with increased capital investment from abroad, wealth disparities among the population became all the more evident, and coca dealing became a prominent business in the country. As a reaction, opposition leftist grassroots organizations increased in number, and the guerrillas grew in strength and popularity. Simultaneously, all social systems, such as education and the legal system, became militarized, increasing the perception of the government as illegitimate. In such a context, a critical criminology began to develop in Colombia and with it a more consistent critical criminological community. Several young scholars dedicated their professional activity to research "the selective character of the penal law and the penal system, and showed how the penal law contributed to class domination" (Benavides Banegas, 2017, p. 17).

In November 1985, State actors murdered Emiro Sandoval Huertas and Alfonso Reyes Echandía-central figures Colombian critical criminology-during the Palace of Justice siege (in which members of the M-19 guerrilla group took over the Palace of Justice in Bogotá and held the Supreme Court of Colombia hostage). By 1990, having seen the key figures of criminology murdered by the State, others grew disenchanted with what they saw as purely academic work with no repercussions 
in "real life" developed by criminology, and decided to focus on their work as lawyers and advocates in order to have a more profound impact on society.

Despite the formation of a criminological community-one critical of state violence, militarism and oppression-this third period emerged as an unimaginative self-denominated criminology in Colombia, reliant mainly on foreign texts and concepts. Silva (2012) points out that in this period, as well as in the ones before and after, Colombian criminologists limited themselves to applying European and North American ideas. Marroquín Grillo and Camacho Flórez (1985) characterized Colombian critical criminology as lacking interdisciplinarity, being theoretically inconsistent, unoriginal, and disengaged from social and political movements, although Emiro Sandoval Huertas and Alfonso Reyes Echandía, murdered by the state for their political activism, serve as exceptions.

The Second Criminological Silence (1990-2000) and Fragmentation (2000-present)

The tragedy of the Palace of Justice siege marked the beginning of the second criminological silence. During this time, economists took the lead in developing studies about criminal justice issues guided by foreign ideas, such as actuarial criminology, the "broken windows" perspective, and the concept of "zero tolerance." And it was during this time that the penal system transformed into a mechanism to control "undesired" populations (Benavides Vanegas, 2008). This second criminological silence ended when a new generation of criminologists returned to Colombia after completing their studies abroad. Benavides Vanegas (2017) characterizes this time of criminology in Colombia as the "fragmentation period"-one in which current criminologists have undertaken new and more imaginative criminological endeavors, albeit in a piecemeal fashion. Although most current Colombian criminologists have received their criminology degrees from institutions abroad, they are nevertheless developing empirical work on Colombian realities, while trying to challenge northern produced theories (for example, Goyes 2019). Nevertheless, the emergence and development of empirical work focusing on contemporary Colombia does not equate to subverting cognitive colonialism. As in the case of South Africa, which we explore next, Colombia has a long history of colonialism; one consequence of this has been that Colombian criminologists-many times unconsciously-have continued to replicate colonial practices of knowledge imposition.

\section{Criminology in South Africa}

South Africa's long, bleak history of colonial and neo-colonial exploitation stretches back over 350 years to the arrival of the first European settlers in 1652. The influence of northern thinking and practice on crime and criminal justice is evident throughout the colonial period. Clare Anderson (2016: 442), for example, has shown how the carceral regimes in place in the Cape Colony during the 
nineteenth century can be understood only in the context of the "local, regional and global mobility of ideas, practices, officials and convicts" circulating in the British imperial world.

When South Africa became a self-governing dominion in 1910, Europe continued to be a fertile source of ideas for policy-makers, practitioners and scholars working in criminology in South Africa. Dirk Van Zyl Smit (1989; 1990; 1999) identifies three broad traditions of South African criminology. First, legal reformists, such as Jacob de Villiers Roos, the first Secretary of Justice and Director of Prisons of the Union of South Africa, adopted an eclectic mix of enlightened neo-classicism and scientific positivism in consolidating the prison system in the years after 1910 (Van Zyl Smit 1990), while the Lansdown Commission of Inquiry on Penal and Prison Reform of the late 1940s represented the "apogee of the 'liberal' pragmatic criminology" of an English-speaking penal-welfare elite (Van Zyl Smit 1989: 242).

When the National Party came to power in 1948, at least part of the rationale for the system of apartheid it began to introduce derived from the intellectual labors of criminologists working in a second, Afrikaner nationalist, tradition. Educated in Europe, members of the National Party drew inspiration from notions of racial superiority and the dangers of racial mixing circulating in Germany and elsewhere during the inter-war years (Van Zyl Smit 1989; 1990). Indeed, as Van Zyl Smit (1989: 234) writes, their "European scholarship" was the "warrant of the authenticity of the ideas" of Geoff Cronjé and W. A. Willemse, the two leading lights of early Afrikaner criminology.

The third tradition-what Van Zyl Smit (1989) calls "a criminology for a democratic South Africa"-also had European origins. It claimed to draw on the "the intellectual heritage of international radical and critical criminology" as the basis for both theoretical deconstruction and practical intervention (Van Zyl Smit 1999: 200). As white minority rule crumbled in the late 1980s, and negotiations for a transfer of power took place in the early 1990s, criminologists working in this tradition sought to appeal to a majority government-in-waiting casting about for new ways of thinking about crime, and more enlightened responses to it.

Although criminology in the Global North impacted the development of criminology in South Africa through much of the twentieth century, local inflections were apparent. For example, Cronjé took the economic determinism and anti-capitalism of Bonger, one of the founders of critical criminology, to "explain" the problem of "poor white" Afrikaners. For Cronjé, the blame for their destitution and depravity could be laid at the door of British colonial exploitation and, much less plausibly, the criminogenic effects of the mixing of "races." The possibility of adapting European ideas to the specific context of the South Africa did not escape Cronjé's contemporary, W. A. Willemse, either, and the latter's Afrikaans text on criminology, published in 1933, included a chapter on the 
"Special crime problems of the Union of South Africa" (Willemse and Rademeyer 1933, cited in Van Zyl Smit 1989: 232).

Criminologists in the liberal reformist and democratic South Africa traditions were also forced to innovate as they grappled with the challenges of working in the hostile environment of apartheid South Africa. New ways of thinking and acting were needed as these critics of the prevailing nationalist orthodoxy struggled to expose the contradictions inherent in a system with pretensions to legality, ameliorate its effects, and give succor to those committed to overthrowing it entirely (Van Zyl Smit 1989; 1999).

Over the last decade of the twentieth century and into the new millennium, scholars and activists eager to overthrow the hegemony of Afrikaner nationalism, offered a radical alternative to liberal reformism as a replacement discourse, and seeking solutions to the problems of the new, democratic South Africa that emerged in 1994, turned to the critical criminologies and policy prescriptions of the Global North (Dixon 2004). Attempts were made to manufacture a "progressive realism" from the raw materials provided by British left realism and feminist critiques of its "androcentrism" (Hansson 1993; 1995), and to bend Jock Young's (1999) analysis of the bulimic tendencies evident in contemporary Euro-America to forms of economic and social exclusion emerging in post-apartheid South Africa (Dixon 2001). But, with so many of its advocates busying themselves with the urgent task of building a new nation, the differences between erstwhile radicals and adherents of the other two traditions-nationalist and reformist-became increasingly hard to detect with the emergence of an over-arching "can-do," policy-focused administrative criminology (Dixon 2004).

Insofar as fault lines in South African criminology have persisted into the democratic era, they have as much to do with institutional history as epistemology. The criminology taught and practiced at the University of Pretoria (UP) and University of South Africa (Unisa), and other institutions with large undergraduate teaching programs, tends to be more conservative and neo-positivist in its orientation than it is at the University of Cape Town (UCT) and in the non-governmental organizations, such as the Institute for Security Studies, which commission and/or conduct some of the most influential research. The introduction to a textbook written by authors based mainly at UP and Unisa, and aimed at a domestic undergraduate audience, contains the following statement: "Although any science-and therefore criminology too-ought to be objective and value free, it is not always the case" (Bezuidenhout and Little 2011: 24). Contrast this assertion with what two authors, one based at UCT, have to say about their approach to research in a contribution to an edited collection produced for an international, but primarily northern and academic, readership: "[We] have never bought into 
preoccupations with 'objectivity' and neutral representations of the social world that do not recognize the place of values in selecting subject-matters" (Shearing and Marks 2011: 131). Stark though the difference between these two approaches may be, one thing that all four authors agree on is the need for South African criminologists to break free of the "Euro-American mentality" and the pervasive belief that "the West knows best" (Shearing and Marks 2011: 139, punctuation in original), and, in the words of Bezuidenhout and Little (2011: 25), to move beyond an "over-reliance on imported ideas" and "Africanise" criminological theory.

Since these sentiments were expressed, the pressure to decolonize the curriculum across higher education in South Africa has mounted, reaching a crescendo during the student protests of 2015-16 and the \#RhodesMustFall movement centerd on the removal of a statue of Cecil Rhodes from the campus at UCT. Precisely what decolonizing the curriculum might entail is not always clear but, at the very least, it implies a commitment to "an Africanisation or indigenisation of the syllabus," changes to the way knowledge is understood, whose knowledge it is, who produces it, how it is taught and by whom (Council for Higher Education 2017: 2). The reaction to these pressures has varied by discipline. Although the meaning, nature and status of ubuntu-often reduced in English to the overly simplistic notion that "a person is a person through other persons" - as a foundational ontological and epistemological concept (Ramose 2005) has been much-debated by philosophers (for a critique, see Matolino and Kwindingwi 2013), it has been adopted as a framework for social theory, political ideals and public policy (Nkondo 2007), and as a moral grounding for a range of human rights in South Africa's post-apartheid Constitution (Metz 2011). Elsewhere, Mangcu (2016: 57) has pointed to the "dissonance between the taken-for-granted assumptions of the White academy and the lived reality of race among Black students" and has called for Black perspectives on race to be placed at the center of the curriculum in South African sociology.

The sense that criminology too has to make room for excluded knowledge and confront its blind spots-for instance, in relation to the trans-historical links between the cultural, physical, psychological and structural violence of the colonial/apartheid era and contemporary problems of "criminal" violence (Henkeman 2013) - has become ever more palpable since 2011. So, and only by way of example, Jonny Steinberg (2016: 515) has warned of the dangers of accepting too readily the "the shiny concepts that are the product of someone else's labour" (David Garland's work on crime control being the case in point) in a way that ends up "occluding rather than illuminating complex social processes in disparate societies." Similarly, Vanessa Barolsky (2016: 27) has questioned the relevance of northern notions of social cohesion and collective efficacy taken from the work of Sampson and colleagues (1997), among others, in the context of a poor, peri-urban township like Khayelitsha, near Cape Town, where a communitarian world view, and social networks underpinned 
by notions of ubuntu, "support forms of mutual sociality that are intrinsic to social life and identity," but may just as easily give rise to violence as peaceful intervention on another's behalf. And finally, the challenge of designing "safe neighbourhoods" in places where high rates of unemployment are accompanied by similarly elevated levels of violence has been taken up by Paula Meth and Sibongile Buthelezi (2017), using the conceptual framing of southern criminology to center experiences of dispossession, crime and injustice among residents of a new housing development relocated from one of South Africa's many informal settlements.

One area in which South Africa is particularly well-placed to contribute a distinctive southern perspective in criminology is in relation to policing, where Clifford Shearing and his various collaborators have demonstrated that security, in the sense of a "liveability" or "liveableness," derived roughly from the notion of ubuntu, can be enhanced by mobilizing and making use of situationallygrounded knowledge and resources within poor communities (Froestad and Shearing 2013). While Froestad and Shearing (2013) acknowledge that the state and its police should continue to hold a monopoly on the use of coercive force, they suggest that, in townships like Zwelethemba, outside Worcester in the Western Cape Province, where they worked for several years, such coercive force cannot act as the sole guarantor of communal or individual safety. In these circumstances, Froestad and Shearing (2013) argue that it makes sense to build the capacity and improve the performance of non-state actors who actually deliver security and justice. Implicit in this reconceptualization of security and its governance is an equally radical shift in the focus of ordering activities from discrete events defined as "crime" by the state, and involving one or more distinct "offenders" and "victims," to a much wider range of problems or troubles with complex histories (and the potential to lead to more difficulties in the future) to which individuals may have contributed in many different ways at different times. What Shearing and his colleagues discovered from their experiments in Zwelethemba, reflects the findings of research by Mnisi Weeks (2018) on "vernacular dispute management forums" in Msinga, a desperately poor, deeply rural area in the eastern province of KwaZulu-Natal. Here, too, the state tends to operate as one removed from the day-to-day work of resolving a wide range of disputes undertaken by local headmen and other actors in a complex network of forums. And here, too, these disputes often came with extensive back-stories defying both unambiguous definitions of "crime" or "not crime" and any once-and-for-all identification of the parties as either wronged or wrongdoers.

\section{Conclusion}

The hierarchical stratification in knowledge production has stunted the recognition of the contributions that scholars from the Global South have made to critical thinking in criminology. 
Criminology's reach and presence in the Global South has been uneven, attributable, in large part, to northern biases and various geopolitical dimensions (e.g., legacies of colonialism). Throughout most of the twentieth century, many institutional branches of criminology in the Global South have tended to borrow and adapt theories from the Global North, in much the same way as the social sciences more broadly (Connell 2014: 522). In many respects, this borrowing and adapting has entailed deference to imported theories and core assumptions underpinning dominant northern criminological paradigms, such as the affinity for positivism in various countries in Latin America, as well as South Africa, at the turn of twentieth century. Consequently, criminologies of the periphery have largely, and until recently, tended to accept a subordinate role in the global organization of knowledge (Carrington, Hogg, and Sozzo 2016). Language barriers, diversity in legal systems and crime control practices, and limitations in resources (Liu 2009) have also hampered the development of and respect for criminology in the Global South. But as is evident from the overviews above, this is changing and a burgeoning southern criminology is contributing to a more nuanced understanding of the context and contours of crime, violence and justice in the Global South.

What is striking is that critical studies of crime, crime control, punishment and state violence in the Global South, in general, and in the countries discussed in this article, in particular, did not arise in a vacuum. Rather, they emerged at times of resistance-resistance to the rise of military dictatorships in Argentina, Brazil and Colombia, to apartheid in South Africa, and to demands for democracy and relaxation of communist and authoritarian rule in parts of Asia. What is also evident is that if we look beyond criminology in these countries to a wider field of social science research on crime, punishment and violence-such as to studies of genocide-of los desaparecidos (thousands of missing presumed murdered by brutal military regimes) -in Argentina; to empirical studies of violence and femicide in Brazil; to research on/in violentology in Colombia; and to research on the violence and brutality of apartheid in South Africa-an abundance of critical work can be found in the Global South. But to do so requires looking beyond the discipline of criminology to anthropologists, historians, lawyers, political scientists, social psychologists and sociologists who have applied their critical lens to questions of crime and harm, justice and punishment, violence and restitution. The fact that these valuable contributions have been, until recently, ignored, reveals criminology's "epistemological blindness." As described by Goyes and South (2017:169), "efforts to detect criminological literature of relevance are always directed to established literatures and databases," reflecting the assumption that knowledge of relevance to criminology has flourished only in Anglophone countries. As such, this mapping of the criminologies of the south is not a piece of comparative criminology, but a process aimed at nourishing the overall global criminological repertoire with injections of critical thinking from outside the Global North. Global innovative forms of restorative and transitional justice in the 
twentieth century have been inspired, for example, by ubuntu, mentioned above - the contested but customary form of social control in South Africa (Matolino and Kwindingwi 2013; Metz 2011; Ramose 2005); the emergence in the 1980s of women's police stations to address gendered violence in Latin America (Carrington and Barberet 2018; Carrington et al 2019); and the role of transitional justice in Argentina in the aftermath of mass atrocities (such CONADEP) (Zysman, 2018). These innovations have had an enduring impact on both social movements and the academic study of femicide, gendered violence, genocide, state crime, and transitional justice.

The rise of criminologies in the Global South provides lessons for developing a more inclusive, critical and globally-oriented criminology (Carrington et al., 2019). Bridging the gap between the Global North and Global South is an important step toward cognitive justice. While this gap presents challenges, it also presents opportunities for scholars from across the Global North and South to collaborate. On pondering what is "critical criminology," Carlen (2002:244) muses that "all knowledge production is, ideally supposed to be critical." What is critical about critical criminology, then, is not a pre-determined set of abstract concepts produced in the Global North, but an approach that offers a counter voice (Young 2002:259) -that refutes state-bound definitions of criminality, that counters the punitiveness of criminal justice systems, and that exposes the global forces that widen inequalities at the root of much criminality (Currie, 2002:vii). Critical thinking probes and ponders the unthinkable, imagines the unimaginable, speaks the unspeakable, and constantly questions the conditions of possibility (Carlen, 2002:244-49). The southernizing of criminology-a project of retrieval that challenges the Global Northern dominance of criminology-is an important journey for all who identify with critical thinking within and outside of the discipline. While this article can only make a very small contribution from a selected number of countries from the Global South, it is our sincere hope that others may be inspired to join the journey, fill in the gaps, and bridge global divides.

\section{References}

Aas, F. (2012). 'The Earth Is One by the World Is Not': Criminological Theory and Its Geopolitical Divisions. Theoretical Criminology 16(1): 5-20. doi-org.ezp01.library.qut.edu.au/10.1177/1362480611433433 Adorno, Sérgio (1988) Os Aprendizes do Poder. Rio de Janeiro: Paz e Terra.

Agnew, R. (1992). Foundations for a General Strain Theory of Crime and Delinquency. Criminology 30 :(1): 47-97. https://doi-org.ezp01.library.qut.edu.au/10.1111/j.1745-9125.1992.tb01093.x

Agnew, R. (2014). The origin of strains: why certain events and conditions are disliked. Paper presented at the annual meeting of the American Society of Criminology, San Francisco. 20 November 2014.

Agnew, R. (2015). Using general strain theory to explain crime in Asian societies. Asian Journal of Criminology, 10 (2), 131-147. https://doi-org.ezp01.library.qut.edu.au/10.1007/s11417-014-9198-2

Agozino, B. (2010) What is criminology: a control freak discipline. African Journal of Criminology and Justice Studies, 4 (1) i-xx. 
Alvarez, Marcos César (2003) Bacharéis, Criminologistas e Juristas: Saber Jurídico e Nova Escola Penal no Brasil. São Paulo: IBCCrim, 2003.

Anderson, C. (2016) Convicts, Carcerality and Cape Colony Connections in the 19th Century. Journal of Southern African Studies, 42:3, 429-442. doi.org/10.1080/03057070.2016.1175128

Andrade, Vera Regina (1997) Criminologia e Feminismo: da mulher como vítima à mulher como sujeito de construção da cidadania. Sequência, 18 (35): 42-49.

Aniyar de Castro, L. (1987). Criminología de la liberación [Liberation criminology]. Maracaibo: Editorial de la Universidad de Zulia.

Bao, Wan-Ning, Ain Haas, Xiaojin Chen, and Yijun Pi. (2014). "Repeated Strains, Social Control, Social Learning, and Delinquency: Testing an Integrated Model of General Strain Theory in China". Youth \& Society 46 (3): 402-424.

Baratta, A. (1986) Criminología crítica y Crítica del derecho penal, Mexico, Siglo XXI

Barberet, R. and Carrington, K. (2018) Globalizing feminist criminology: Gendered violence during peace and war. In Carrington K, Hogg R, Scott J and Sozzo M (eds) The Palgrave Handbook of Criminology and the Global South: 821-846. Cham, Switzerland: Palgrave Macmillan.

Barolsky, V. (2016) 'Is social cohesion relevant to a city in the Gglobal South?' South African Crime Quarterly, 55: 17-30.

Barreto, Tobias (2003/1894) Menores e Loucos em Direito Criminal. Estudo sobre o art. 10 do Código Criminal do Império. Brasília: Senado Federal.

Batista, Nilo (1990) Punidos e Mal Pagos. Rio de Janeiro: Revan.

Batista, Vera Malaguti (2011) Introdução Crítica à Criminologia Brasileira. Rio de Janeiro: Revan.

Beato, Cláudio (2012) Crimes e Cidades. Belo Horizonte: Ediotra da UFMG.

Belknap, Joanne. (2016). "Asian criminology's expansion and advancement of research and crime control practices." Asian Journal of Criminology 11(4): 249-264. doi: 10.1007/s11417-016-9240-7.

Benavides Banegas, F. S. (2009). Criminal law as a constitutive strategy: The Colombian case. New Mexico: Latin American Institute.

Benavides Banegas, F. S. (2017). La criminología crítica en Colombia [Critical criminology in Colombia]. In F. S. Benavides Banegas (Ed.), Criminología en Colombia [Criminology in Colombia] (pp. 15-33). Bogotá: Ibañez.

Benavides Vanegas, F. S. (2008). A global zero tolerance? Colombian prisions from a world historical perspective. Pensamiento Jurídico (23), 173-202.

Benevides, Maria Victoria. (1983) Violência, povo e polícia: violência urbana no noticiário de imprensa. São Paulo: Brasiliense.

Bergalli, R (1972) Criminología en América Latina. Buenos Aires: Pannedille.

Bergalli, R (1982) Crítica a la criminología. Bogotá. Temis.

Bergalli, R. (1989). Poder Político y derechos humanos en América Latina (autoritarismo y democracia). Nuevo Foro Penal, 43, 83-106.

Bezuidenhout, C. and Little, K. (2011) 'Crime and criminology', in Bezuidenhout, C. (ed.) A Southern African Perspective on Fundamental Criminology. Cape Town: Heinemann, pp. 2-39.

Bowling, B. (2011) Transnational criminology and the globalisation of harm production. In Bosworth $\mathrm{M}$ and Hoyle C (eds) What is Criminology? (pp. 361-379). Oxford: Oxford University Press.

Braihwaite, J. (2015). "Rethinking Criminology through Radical Diversity in Asian Reconciliation." Asian Journal of Criminology, 10 (3) 183-91 doi: 10.1007/s11417-014-9200-z.

Braithwaite, J. (2014). "Crime in Asia: Toward a better future." Asian Journal of Criminology 9(1): 65-75. doi: 10.1007/s11417-013-9176-0.

Brown, M. (2018) "Southern Criminology in the Post-colonality: More than a derivative discourse' The Palgrave Handbook of Criminology and the Global South. Carrington, K Hogg R, Scott, J, Sozzo, M (eds) Cham, Switzerland: Palgrave Macmillan.

Cain, M. (2000) Orientalism, Occidentalism and the Sociology of Crime. The British Journal of Criminology, 40 (2) :pp 239-260260) 2000. https://doi.org/10.1093/bjc/40.2.239

Cancelli, Elizabeth (2001) A Cultura do Crime e da Lei: 1899-1930. Brasília: Editora Universidade de Brasília. 
Cao, L Hebenton B (2018) "Criminology in China: Taking Stock (Again)", The Criminologist, 43 (2) 1-5.

Cao, L. (2008). "A Third Eye on Chinese Criminology." Available from: http://enroute.fyfz.cn/blog/enroute/index.aspx?blogid=395746

Carlen, P. (2002) Critical Criminology? In praise of an oxymoron and its enemies. In K. Carrington and R. Hogg eds, Critical Criminology (pp 243-250). Collumpton, Devon, UK: Willan.

Carrington K. (2017a) Asian Criminology and Southern Epistemologies. In: Liu J., Travers M., Chang L. (eds) Comparative Criminology in Asia. (pp. 61-69) Springer Series on Asian Criminology and Criminal Justice Research. Springer, Cham, Switzerland

Carrington, K. Hogg, R. (2017) 'Deconstructing Criminology's Origin Stories', Asian Journal of Criminology, 12 (3)_pp 181-197 pp. 1-17 first published on-line April 201. 7, doi: 10.1007/s11417-017-9248-7.

Carrington, K. Hogg, R. Scott, J, Sozzo, M and Walters, R (2019) Southern Criminology, Routledge, London and New York.

Carrington, K. Hogg, R. Scott, J. and Sozzo, M. (eds) (2018) The Palgrave Handbook of Criminology and the Global South. Cham, Switzerland: Palgrave Macmillan.

Carrington, K., Hogg, R., \& Sozzo, M. (2016). "Southern criminology." The British Journal of Criminology 56(1): 1-20. doi: 10.1093/bjc/azv083.

Cartagena, C. (2016). Los estudios de la violencia en Colombia antes de la violentología [Studies of violence in Colombia before violentology]. Diálogos Revista Electrónica de Historia, 17(1), 63-88.

Castro, L. A. D. (1987). Criminología de la liberación. Maracaibo: Editorial de la Universidad del Zulia. Castro, L. A. D. (1987). Criminología de la liberación. Maracaibo: Editorial de la Universidad del Zulia.

Chakrabarty, D. (2000) Provincializing Europe: Post-Colonial Thought and Difference, 2nd edn. Princeton: Princeton University Press.

Cheung, Chau-Kiu, Ngan-Pun Ngai, and Steven Sek-Yum Ngai. (2007). "Family Strain and Adolescent Delinquency in two Chinese cities, Guangzhou and Hong Kong." Journal of Child and Family Studies 16 (5) :626-641. https://doi-org.ezp01.library.qut.edu.au/10.1007/s10826-006-9112-3

Cheung, N. W. T., \& Cheung, Y. W. (2010). "Strain, Self-Control, and Gender Differences in Delinquency among Chinese Adolescents: Extending General Strain Theory." Sociological Perspectives 53 (3) : 321345. https://doi-org.ezp01.library.qut.edu.au/10.1525/sop.2010.53.3.321

Clark, D. (ed.). (2012). Comparative Law and Society. Edward Elgar, Cheltenham.

Comaroff, J. and Comaroff, J L. (2011) Theory from the South: Or, how Euro-America is evolving towards Africa. Boulder: Paradigm Publishers.

CONADEP (1984) Nunca Más. Buenos Aires: Eudeba.

Connell R, Collyer F, Maia J and Morrell R (2017) "Toward a global sociology of knowledge: Post-Colonial realities and intellectual practices". International Sociology 32 (1): 21-37. DOI: $10.1177 / 0268580916676913$.

Connell, R. (2007). Southern Theory: The Global Dynamics of Knowledge in Social Science. Sydney: Allen and Unwin.

Council for Higher Education (2017) 'Decolonising the curriculum: stimulating the debate', Briefly Speaking 3: 1-12: http://www.che.ac.za/media and publications/monitoring-and-evaluation/brieflyspeaking3-curriculum-decolonisation.

Cunneen, C. (2011) Postcolonial Perspectives for Criminology. In Bosworth, M. \& Hoyle, C. (eds), What is Criminology?, Oxford University Press, United Kingdom, pp. 249-266.

Cunneen, C. (2018) Indigenous challenges for Southern Criminology. In K Carrington, Hogg R, Scott J and Sozzo M (eds) The Palgrave Handbook of Criminology and the Global South: 19-42. Cham Switzerland:Palgrave.

Currie, E. (2002) "Preface”. In K. Carrington and R. Hogg eds, Critical Criminology (pp. vii-x). Collumpton, Devon, UK: Willan.

Currie, E. (2017). Confronting the North's South: On Race and Violence in the United States. International Journal For Crime, Justice And Social Democracy, 6(1), 23-34. DOI: 10.5204/ijcjsd.v6i1.382.

de Sousa Santos, B. (2014) Epistemologies of the South: Justice Against Epistemicide. Boulder: Paradigm Publishers. 
del Olmo R (1981) América Latina y su criminología, México: Siglo XXI.

del Olmo R (1990) Criminología argentina: apuntes para una reconstrucción histórica. Buenos Aires: Depalma.

Dias, Rebeca Ferreira (2017) Criminologia no Brasil: Cultura Jurídica Criminal na Primeira República. Rio de Janeiro: Lumen Juris.

Dixon, B. (2001) 'Exclusive societies: towards a critical criminology of post-apartheid South Africa', Society in Transition, 32(2): 205-227. doi-org.ezp01.library.qut.edu.au/10.1080/21528586.2001.10419043

Dixon, B. (2004) 'In search of interactive globalisation: critical criminology in South Africa's transition' Crime, Law and Social Change, 41(4): 359-384. doiorg.ezp01.library.qut.edu.au/10.1023/B:CRIS.0000025767.67115.f2

Fals Borda, O., Umaña, E., \& Guzmán Campos, G. (2016 [1962]). La violencia en Colombia [Violence in Colombia]. Bogotá: Taurus.

Ferla, Luís. (2009) Feios, Sujos e Malvados sob Medida: A utopia médica do biodeterminismo, São Paulo (1920-1945). São Paulo: Alameda.

Fonseca, David S. (2018). Expansion, standardization, and densification of the criminal justice apparatus: Recent developments on Brazil. Punishment \& Society, 20 (3): 329-350. https://doiorg.ezp01.library.qut.edu.au/10.1177/1462474517694504.

Froestad, J. and Shearing, C. (2013) Security Governance, Policing, and Local Capacity. Boca Raton: CRC Press.

Gottfredson, Michael R. (2006). "The Empirical Status of Control Theory in Criminology." pPp. 77-100 in Taking Stock: The Status of Criminological Theory. Advances in Criminological Theory Vo. 15, edited by Francis T. Cullen, John Paul Wright, and Kristie R. Blevins. New Brunswick, NJ: Transaction.

Goyes, D. R. (2015). Land Uses and Conflict in Colombia. In A. Brisman, N. South, \& R. White (Eds.), Environmental Crime and Social Conflict. (pp. 503-18) Surrey, England: Ashgate.

Goyes, D. R. (2018). Green Criminology as Decolonial Tool: A Stereoscope of Environmental Harm. In K. Carrington, R. Hogg, J. Scott, \& M. Sozzo (Eds.), The Palgrave Handbook of Criminology and the Global South (pp. 323-346). UK: Palgrave.

Goyes, D. R. (2019) Green Southern Criminology. Science against ecological discrimination. (Book Series Perspectives on Crime, Law and Justice from the Global South). Emerald

Goyes, D. R., \& South, N. (2017). 'Green Criminology before Green Criminology': Amnesia and Absences. Critical Criminology, 25(2), 165-181. oi-org.ezp01.library.qut.edu.au/10.1007/s10612-017-9357-8

Hansson, D. (1993) 'Feminist scholarship and progressive realist criminology in contemporary South Africa - preferred relations and future directions', Paper delivered at the British Society of Criminology Conference, University of Wales, Cardiff, 28-31 July.

Hansson, D. (1995) 'Agenda-ing gender: feminism and the engendering of academic criminology in South Africa', in N. Hahn Rafter and F. Heidensohn (eds), International Feminist Perspectives in Criminology. Buckingham: Open University Press, pp. 39-60.

Henkeman, S. (2013) 'Pale face'/'pointy face': SA criminology in denial', South African Crime Quarterly, 45: 5-11.

Hogg, R., Scott, J., \& Sozzo, M. (2017). “Southern Criminology: Guest Editors' Introduction”. International Journal For Crime, Justice And Social Democracy, 6(1), 1-7. DOI: 10.5204/ijcjsd.v6i1.395.

http://dx.doi.org.ezp01.library.qut.edu.au/10.1037/0033-295X.108.2.291

Hungria, Nelson. (1943) A evolução do direito penal brasileiro. Revista Forense, jul. 1943

Ingenieros J (1916). Criminología. Buenos Aires: Claridad.

Jiang, S., Land, K. C., \& Wang, J. (2013). "Social ties, collective efficacy and perceived neighborhood property crime in Guangzhou, China." Asian Journal of Criminology 8(3): 253-269 https://doiorg.ezp01.library.qut.edu.au/10.1007/s11417-013-9167-1

Kauzlarich, D. (2013). Editor's introduction to the special issue: "crucial critical criminology". Critical Criminology, 21(3), 255-256. doi:http://dx.doi.org.ezp01.library.qut.edu.au/10.1007/s10612-0139209-0.

Lansdown, C. (1947) Report of Penal and Prison Reform Commission. Pretoria: Government Printers. 
Leavitt, G. (1990). "Relativism and cross-cultural criminology: A critical analysis." Journal of Research in Crime and Delinquency 27(15): 5-29.

Lima, Renato Sérgio de Ratton, José Luiz (org) (2011) As Ciências Sociais e os pioneiros nos estudos sobre crime, violência e direitos humanos no Brasil. São Paulo: Fórum Brasileiro de Segurança Pública; Urbania; ANPOCS.

Liu J, Travers M and Chang LYC (2017) (eds) Comparative Criminology in Asia. New York: Springer.

Liu, J. (2009). "Asian Criminology - Challenges, Opportunities and Directions." Asian Journal of Criminology 4 (1) : 1-9. DOI 10.1007/s11417-009-9066-7

Liu, J. (2017). The Asian Criminological Paradigm and How It Links Global North and South: Combining an Extended Conceptual Toolbox from the North with Innovative Asian Contexts. International Journal For Crime, Justice And Social Democracy, 6(1), 73-87. DOI: 10.5204/ijcjsd.v6i1.385.

Liu, J., Ganapathy, N., \& Balachandran, L. (2016). Asian Paradigm Theory and Access to Justice. Journal of Contemporary Criminal Justice, 32(3), 205-224. https://doi.org/10.1177/1043986216656681

Liu, J., Hebenton, B. and Jou, Susyan. (eds.) (2013) Handbook of Asian Criminology. Springer, New York.

Lyra Filho, Roberto (1972) Criminologia Dialética. Rio de Janeiro: Borsoi, 1972.

Mangcu, X. (2016) 'Decolonizing South African sociology: building on a shared 'text of blackness", Du Bois Review, 13(1): 45-59.

Marroquín Grillo, G., \& Camacho Flórez, J. (1985). Apuntes para la historia de la criminología en Colombia [Notes for the history of criminology in Colombia]. Derecho Penal y Criminología, 283, 283-293.

Matolino, B. and Kwindingwi, W. (2013) 'The end of ubuntu', South African Journal of Philosophy, 32(2): 197-205.

Mattei, U. (2006). "Comparative law and critical legal studies". In M.Reimann and R, Zimmerman, R. (eds.) The Oxford Handbook of Comparative Law. Oxford University Press, Oxford, pp.815-836.

Medina Gallego, C. (2009). FARC-EP. Notas para una historia política (1958-2008) [FARC-EP. Notes for a political history]. Bogotá: Universidad Nacional de Colombia.

Messner, S. (2015). "When west meets east: generalizing theory and expanding the conceptual toolkit of criminology." Journal of Asian Criminology. 10 (2) 117-129 doi:10.1007/s11417-014-9197-3.

Messner, S. F. (2014). "Social institutions, theory development, and the promise of comparative criminological research." Asian Journal of Criminology 9 (1): 49-63. doiorg.ezp01.library.qut.edu.au/10.1007/s11417-013-9175-1

Meth, P. and Buthelezi, S. (2017) 'New housing/new crime? Changes in safety, governance and everyday incivilities for residents relocated from informal to formal housing at Hammond's Farm, eThekwini', Geoforum, 82: 77-86.

Metz, T. (2011) 'Ubuntu as a moral theory and human rights in South Africa', African Human Rights Law Journal, 11(2): 532-559.

Mnisi Weeks, S. (2018) Access to Justice and Human Security: Cultural Contradictions in Rural South Africa. Abingdon: Routledge.

Mondaca, E. (2017). The archipelago of Chiloé and the uncertain contours of its future: coloniality, new extractivism and political-social re-vindication of existence. In D. R. Goyes, H. Mol, A. Brisman, \& N. South (Eds.), Environmental Crime in Latin America: The Theft of Nature and The Poisoning of The Land (pp. 31-55). UK: Palgrave Macmillan.

Moosavi, L. (2018). Decolonising criminology: Syed hussein alatas on crimes of the powerful. Critical Criminology, 1-14. doi:http://dx.doi.org.ezp01.library.qut.edu.au/10.1007/s10612-018-9396-9.

Nelken, D. (2010). Comparative Criminal Justice. Sage, London.

Ngai, Ngan-Pun, and Chau-Kiu Cheung. (2005). "Predictors of the Likelihood of Delinquency A Study of Marginal Youth in Hong Kong, China." Youth \& Society 36 (4):445-470. doiorg.ezp01.library.qut.edu.au/10.1177/0044118X04267814

Nino C (1996) Radical Evil on Trial: Yale University.

Nisbett, R.E., Peng, K., Choi, I., and Norenzayan, A. (2001). "Culture and systems of thoughts: Holistic versus analytic cognition." Psychological Review, 108 (2), 291-310. 
Nkondo, G. (2007) 'Ubuntu as a public policy in South Africa: a conceptual framework', International Journal of African Renaissance Studies, 2(1): 88-101.

Olmo, Rosa Del (1981) America Latina y su criminologia. Mexico: Siglo XXI.

Paixão, Antônio Luiz (1987) Recuperar ou Punir? Como o Estado trata o criminoso. São Paulo: Cortez.

Pavarini, M. (1983) Control y Dominación. Teorías criminológicas burguesas y proyecto hegemonic, México, Siglo XXI.

Peralva, Angelina. (2000) Violência e Democracia: O Paradoxo Brasileiro. São Paulo: Paz e Terra. Peralva, Angelina. (2000) Violência e Democracia: O Paradoxo Brasileiro. São Paulo: Paz e Terra.

Pimentel, Manuel Pedro (1980) Breve Notas para a História da Criminologia no Brasil. Revista da Faculdade de Direito da UFG, 4 (2): 231-240.

Ramose, M. (2005) African Philosophy through Ubuntu. Harare: Mond Book Publishers.

Reimann, M. and Zimmerman, R. (eds.) (2006). The Oxford Handbook of Comparative Law. Oxford University Press, Oxford.

Rodrigues, Nina (2011/1894) As raças humanas e a responsabilidade penal no Brasil. Rio de Janeiro: Centro Edelstein de Pesquisa Social.

Rusche G \& Kirchheimer O (1984) Pena y estructura social. Bogotá: Temis

Sampson RJ, Raudenbush SW, Earls F. (1997) "Neighborhoods and violent crime: a multilevel study of collective efficacy". Science. 277(5328):918-24.

Sampson, R. J. (2015). "Crime and the life course in a changing world: insights from chicago and implications for global criminology." Asian Journal of Criminology 10(4): 277-286. doiorg.ezp01.library.qut.edu.au/10.1007/s11417-015-9220-3

Santos, Juarez Cirino (1981) A criminologia radical. Rio de Janeiro: Forense. Santos, Juarez Cirino (1981) A criminologia radical. Rio de Janeiro: Forense.

Schwarcz, Lilia Moritz (1993) O Espetáculo das Raças: Cientistas, Instituições e Questão Racial no Brasil. São Paulo: Companhia das Letras.

Schwarcz, Lilia Moritz (1993) O Espetáculo das Raças: Cientistas, Instituições e Questão Racial no Brasil. São Paulo: Companhia das Letras.

Shearing, C. and Marks, M. (2011) 'Criminology's Disney World: the ethnographer's ride of South African criminal justice', in M. Bosworth and C. Hoyle (eds) What is Criminology? Oxford: Oxford University Press, pp. 125-142.

Silva García, G. (2011). Criminología. Teoría sociológica del delito [Criminology. A sociological theory of crime]. Bogotá: ILAE.

Silva García, G. (2012). El estado de la criminología en Colomibia a propósito de la crítica de Luis Jiménez de Asúa [The state of criminology in Colombia regarding the Luis Jiménez de Asúa critique] Diálogos de saberes, 37, 105-114.

Sontag, Ricardo (2009) "A eloqüência farfalhante da tribuna do júri": o tribunal popular e a lei em Nelson Hungria. História, 28 (2): 267-302.

Sontag, Ricardo (2009) "A eloqüência farfalhante da tribuna do júri": o tribunal popular e a lei em Nelson Hungria. História, 28 (2): 267-302.

Sozzo M (2001) 'Traduttore traditore'. Traducción, importación cultural e historia del presente de la criminología en América latina. M Sozzo (coord.) Reconstruyendo las criminologías críticas, Bs. As.: AdHoc.

Sozzo, M. (2011) "Cultural Travels and Crime Prevention in Argentina" in Melossi, D, M. Sozzo and R. Sparks (eds). Travels of the Criminal Question: Cultural Embedeness and Diffusion, Oxford/Portland, Hart, 185-216.

Steinberg, J. (2016) 'How well does theory travel? David Garland in the global South', Howard Journal of Criminal Justice, 55(4): 514-531.

Takagi, D., \& Kawachi, I. (2014). "Neighborhood social heterogeneity and crime victimization in Japan: Moderating effects of social networks." Asian Journal of Criminology 9(4): 271-284.

Taylor I Walton P. \& Young J (1977) La Nueva Criminología. Contribución a una teoría social de la conducta desviada. Buenos Aires: Amorrortu. 
Travers, M. (2017) The idea of a Southern Criminology. International Journal of Comparative and Applied Criminal Justice. 43 (1) : 1-12 Epub ahead of print 26 October. DOI: 10.1080/01924036.2017.1394337.

Valladares, Lícia (2000) A gênese da favela carioca: a produção anterior às ciências sociais. Revista Brasileira de Ciências Sociais, 15 (44): 5-34.

Van Zyl Smit, D. (1989) 'Adopting and adapting criminological ideas: criminology and Afrikaner Nationalism in South Africa', Contemporary Crises, 13: 227-251.

Van Zyl Smit, D. (1990) 'Introduction: contextualising criminology in contemporary South Africa', in D. Hansson and D. Van Zyl Smit (eds) Towards Justice? Crime and State Control in South Africa. Cape Town: Oxford University Press, pp. 1-16.

Van Zyl Smit, D. (1999) 'Criminological ideas and the South African transition', The British Journal of Criminology, 39(2): 198-215.

Waisselfisz, Julio Jacobo (2011) Mapa da Violência 2012: Os novos padrões da violência homicida no Brasil. São Paulo: Instituto Sangari.

Walklate, S. (2016). "Whither criminology: Its global futures?" Asian Journal of Criminology 11(1): 47-59. doi: 10.1007/s11417-015-9223-0.

Wong, Dennis S. W. (2001). "Pathways to Delinquency in Hong Kong and Guangzhou (South China)." International Journal of Adolescence and Youth 10 (1-2):91-115.

Young, J. (1999) The Exclusive Society. London: Sage.

Young, J. (2002) Critical Criminology in the twenty-first century: critique, irony and the always unfinished. In K. Carrington and R. Hogg eds. Critical Criminology (pp. 250-74). Collumpton, Devon, UK: Willan.

Zaffaroni, E R (1993) Criminología. Aproximación desde un margen. Botog: Temis.

Zaffaroni, E R (2015) El derecho latinoamericano en la fase superior del colonialismo. Buenos Aires. Madres de Plaza de Mayo.

Zaffaroni, E. R. (1988). Criminología: Aproximación desde un margen. Bogota: Temis.

Zaffaroni, Eugenio R (1982). Política Criminal Latinoamericana. Perspectivas-Diyuntivas. Buenos Aires: Hammurabi.

Zaluar, Alba. (1994) Condomínio do Diabo. Rio de Janeiro: Revan/UFRJ.

Zaluar, Alba; Alvito, Marcos. (1998) Um século de favela. Rio de janeiro: Fundação Getúlio Vargas. Zaluar, Alba; Alvito, Marcos. (1998) Um século de favela. Rio de janeiro: Fundação Getúlio Vargas.

Zysman Quirós D (2017) Punishment, democracy and transitional justice in Argentina (1983-2015) International Journal for Crime, Justice and Social Democracy, 6(1), 88-102. https://doi.org/10.5204/ijcjsd.v5i4.378 .

Zysman Quirós D (2018) Building Social Democracy Through Transitional Justice: Lessons from Argentina (1983-2015) Carrington K, Hogg R, Scott, J \& Sozzo M (eds) The Palgrave Handbook of Criminology and the Global South. Cham Switzerland: Palgrave Macmillan (pp.991-1010).. 